\title{
Factors of best practices of e-learning among
} undergraduate students

Gbolahan Olasina

University of KwaZulu-Natal, South Africa

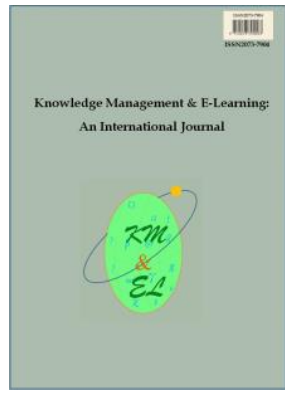

Knowledge Management \& E-Learning: An International Journal (KM\&EL) ISSN 2073-7904

\section{Recommended citation:}

Olasina, G. (2018). Factors of best practices of e-learning among undergraduate students. Knowledge Management \& E-Learning, 10(3), $265-289$. 


\title{
Factors of best practices of e-learning among undergraduate students
}

\author{
Gbolahan Olasina* \\ School of Social Sciences \\ University of KwaZulu-Natal, South Africa \\ E-mail: OlasinaG@ukzn.ac.za \\ *Corresponding author
}

\begin{abstract}
A renewed focus should be on human aspects and change behaviour in the uptake of e-learning. Thus, the overriding purpose of the study was to provide a diagnostic insight into how different factors come into play in the context of best practices of e-learning. The research aimed to help build a robust approach to the phenomenon. A dominant quantitative and less dominant qualitative method using survey approach was adopted. A total of 2,718 undergraduate students of the School of Social Sciences at two campuses of the University of KwaZulu-Natal, UKZN, South Africa participated in the survey. The theoretical framework adopted to underpin the research was the Unified Theory of Acceptance and Use of Technology Model (UTAUT). The findings identified the criticality of factors such as perceived ease of use, complexity, ease of use, attitude, subjective norm, social factors and image to best practices of e-learning. The significance of the study has the potential to impact on the policy, implementation and best practices of e-learning. Theoretically, the context of South Africa in contrast to early adopter countries was employed to advance the frontiers of global knowledge and improve an understanding of the UTAUT model to explain e-learning best practices.
\end{abstract}

Keywords: e-Learning; Best practices; Educational innovation; UTAUT model; Students; South Africa

Biographical notes: Dr. Gbolahan Olasina is a Senior Lecturer, School of Social Sciences, University of KwaZulu-Natal (UKZN), Pietermaritzburg, South Africa. He was a postdoctoral research fellow in the Department of Information Science at the University of South Africa, 2014-2016. He has taught at several leading universities in Africa. His research interests include research methods in the Social Sciences, Digital Life and educational technology, the evolution of paradigms for Africa and socio-informatics. He has several publications in reputable journals.

\section{Introduction}

Most universities commit to e-learning in response to recent social, economic, and pedagogical challenges to tertiary-level teaching and learning, where universities are increasingly investigating and adopting e-learning to engage and motivate students (Bell \& Federman, 2013; Al-Qahtani \& Higgins, 2013). Historically, the impact of technologybased interventions such as e-learning in Africa is limited as a result of approach, strategies and implementation (van Stam \& van Greunen, 2014). While a lot has been written on infrastructure, systems and applications of e-learning systems, there is little 
understanding of best practices of e-learning. Also, other educational technology tools by students for improved engagement, performance and positive experiences in multiple contexts are not well reported in the literature (Tarhini, Teo, \& Tarhini, 2015; Erichsen \& Salajan, 2014; Olasina, 2014, 2016). It is not often that students are the focus of related studies. Besides, existing studies largely focus on identifying and disseminating best practices of broad spectrums of technologies in the context of organisations mainly in Europe (Alhomod \& Shafi, 2012; Bocconi, Kampylis. \& Punie, 2012). Unfortunately, the underlying assumptions that underpin previous studies tend to have a view that such practices can be replicated in other cultures and domains and that dissemination of the best practices originating elsewhere must ultimately lead to improvements in other climes and environments. Tarhini, Hone, and Liu (2013) indicated that due to massive differences in power relations, culture, politics, economy and societal contexts between developed and developing countries, best practices of e-learning in Europe might not inform the practice in South Africa and continental Africa. Even though there may be challenges in replicating the best practices; it is essential to identify existing best practices in a developing country landscape and provide a framework to catalyse best elearning practices and address the shortage of innovation and understanding of approaches to e-learning. Accordingly, it was crucial to use the setting of South Africa not only to add geographical contexts to the body of literature merely but to inform the understanding and knowledge in the area of study globally. Likewise, it was important to focus on categories of users while addressing best practices of e-learning (Osipov, Nikulchev, Volinsky, \& Prasikova, 2015). Consequently, the study covered students using the lens of performance expectancy, effort expectancy, social influence, attitude and facilitating conditions to view the best practices regarding e-learning. The lens of skills and competency, attitude, infrastructure and support and innovation are used to view the critical factors, good practice and inhibitors of e-learning. The context-specific issues addressed by the research included a lack of understanding of the best e-learning practices by students from a developing country setting that are essential elements of positive user experiences and e-learning success. Therefore, framing e-learning systems to align users with best practices is important to users. In fact, regular engagements, investigations and discussions about best practices may be associated with improved user experiences, improved performance, reduction in the frustrations and negative experiences with e-learning and outcome expectations. Thus, the overriding purpose of the study was to contribute to the development and adaptation of best practices of elearning by students identifying and presenting successful approaches. The aim of the study was to review evidence and describe best practices of e-learning by users. Furthermore, another goal was to examine the inhibitors to best practices of e-learning. To put it another way, some researchers argued that the designers of e-learning and educational technologies need to remember that students do not understand the presentation of features and tools inherent in the systems. Also, often, system designers understand the inhibitors from the perspectives of the users (Torrisi-Steele \& Drew, 2013; Teach \& Murff, 2014).

Put succinctly, good or best practices cover getting the best experiences of elearning by students. In other words, the concepts of best practices originate from the criticality of enhancing the quality of e-learning implementation. Fortunately, best practices provide real-life benchmarks and techniques to appropriate e-learning. After all, Edmonds (2006) and Persico, Manca, and Pozzi (2014) presented a summary of good practice that informs strategy, organisation and process, contents and infrastructure. Accordingly, the earlier mentioned authors provide a framework that guided the concept of best practice of e-learning in the present research. Ultimately, best practices in this context cover creativity and innovation, change, improvement, problem-solving and a set 
of practices, standards and guidelines that are easy to adopt and are proven to be efficient to the learning needs of the users. Best practices of e-learning include features for collaborative learning, sharing, eliciting preferences and an understanding of learning goals. Also, best practices include techniques that help reduce stress, fatigue and errors related to the use of e-learning. Also, innovation and creative use are carrying e-learning beyond the poor integration of technology into learning or the teaching and learning of computers. Bazhenov and Luchaninov (2014) report evidence of limited creativity in the use of blended learning systems for the formation of contexts such as humanitarianism of students' creative initiatives at learning new technologies. Consequently, innovation and creativity such as change, alteration, reorganisation, restyling, a new approach, thinking skills, metamorphosis and variation in the approach to e-learning by the students are conceptualised in the current study as best practices. In short, best practices or good practice in this study was framed as a roadmap for the improvement of the e-learning experiences of users. Surprisingly, innovation and creative use are carrying e-learning beyond the poor integration of technology into learning or the teaching and learning of computers. Bazhenov and Luchaninov (2014) report evidence of limited creativity in the use of blended learning systems for the formation of contexts such as humanitarianism of students' creative initiatives at learning new technologies. Likewise, Reiska, Soika, and Cañas (2008) examined the changes and kinds of learning that high school afford science students using the lens of interdisciplinarity. The authors found among others a need to extend our understanding by future research to shed new light on the practices of assessment of interdisciplinary in education. Despite rapid expansion of education and specifically e-learning, there is little attention expressed concerning intra-student frustrations and challenges in defining best practices, innovation and creativity. Thus, innovation and creativity are conceptualised in the current study alongside as change, alteration, reorganisation, restyling, a new approach, thinking skills, metamorphosis and variation in the approach to e-learning by the students. As a result, innovation and creativity are used as the lens to view best practice approaches to the use of e-learning by users.

Consequently, the significance of the study was to improve user experiences by evaluating approaches to the use of e-learning by students. It was fundamental to enhance an understanding of e-learning practices better to meet requirements in a digital age. Thus, the study identified and described a set of best practices for e-learning that have solid foundations in the experiences of students, and that improve their learning activities. Ultimately, the research provided a benchmark for students to view the good practice of e-learning. Also, the study addressed a need to make the users aware of best practices to improve their approaches to e-learning and for institutions to review their standards. Consider that Lonn, Teasley, \& Krumm (2011) called for more research on innovative epractices, issues of post-adoption usage and continuance intention as little research is conducted in the field. Also, the present study provided an evaluation of the e-learning practices using the lens of students to inform the knowledge and an understanding of the area of study. The contextual setting is the e-learning system at the University of KwaZulu-Natal, (UKZN). The system is locally called, LEARN@UKZN. The e-learning practice at the institution is blended (traditional and e-learning systems). Put simply; the current digital environment requires a co-evolution of learning, innovation, creativity as a set of practices for survival. After all, students need new skills to use e-learning and to improve their e-learning experiences. The insights from the study have the potential to guide, inform, create and improve an understanding of best e-learning practices (Divaharan \& Lim, 2010; Divaharan, Lim, \& Tan, 2011). In fact, the findings of the research potentially contribute to learning based pedagogies of experiences, interaction, engagement and immersion in the context of e-learning systems. The anticipated 
contributions improve the understanding of designs and approaches to improve student engagement with e-learning and model advancing pedagogies targeted at further enhancing students' involvement in their e-learning experiences. Finally, the present study used the context of South Africa to extend the frontiers of knowledge of student/user issues regarding best e-learning practices. The following section presents the theoretical perspectives that support the research.

\section{Theoretical framework}

The present research considered the claim by Venkatesh, Morris, Davis, and Davis (2003) that their model addressed the weaknesses of the earlier technology adoption models with the development of the Unified Theory of Acceptance and Use of Technology (UTAUT). In fact, the model is reported in the literature to be successful in related contexts. For example, several authors used the UTAUT model to explain a large proportion of variance in intention and behaviour in users' uptake of technologies such as Tablets Apps, e-taxation and e-learning (Riaz \& Adnan, 2016; Aziz \& Idris, 2016). While, a set of researchers provided empirical evidence to support the appropriateness of the UTAUT model as a theoretical lens for technology related studies across multiple contexts (Lai, Wang, Li, \& Hu, 2016; Moghavvemi, Salleh, \& Abessi, 2013). Also, the suitability of the model to developing countries outside the scope of the developed world where it originated was reported by authors such as Van Winkle, Bueddefeld, MacKay, and Halpenny (2017) and Simeonova, Bogolyubov, Blagov, and Kharabsheh (2014). Thus, the model was deemed diverse and robust enough to be employed to inform the adaptation of best practices of e-learning by students. The model incorporated eight existing models. The primary constructs of the model are performance expectancy, effort expectancy, social influence, attitude and facilitating conditions. The constructs above were related directly to inform the purpose of the current study. The constructs mentioned earlier explained $70 \%$ of total variance in the behavioural intention of users in the adoption and the use of technology (Martins, Oliveira, \& Popovič, 2014).

The core arguments and assumptions of the UTAUT model state that performance expectancy, conceptualised by perceived usefulness, relative advantage, job fit, extrinsic motivation and outcome expectations predict the use of technology. Furthermore, the model argues that effort expectancy represented by perceived ease of use and complexity predict users' approach to technology. While, social influence assumes that as experience with technology increases social contexts exert less impact on the adoption intention because users rely more on opinions of friends, peers and family when uncertainty with technology is high (Workman, 2014). For instance, the fundamental constructs of the UTAUT model framed the themes of the sections of the survey instruments and drove data in the analysis section. Fortunately, Magsamen-Conrad, Upadhyaya, Joa, and Dowd (2015) used the UTAUT model for predicting multi generational tablet adoption practices. The focus of the study was on ageism, gender and the adoption of tablets by the young and oldest generations. The outstanding results showed that effort expectancy and facilitating conditions predicted the adoption of tablet computers. However, the study had limitations as a result of its methodological approaches. Consequently, the current research extended its focus beyond adoption to include innovative practices in the approach to e-learning by students. Also, Fath-Allah et al. (2014) and McDonald et al. (2014) collected best practices and practice-oriented perspectives regarding e-government and social media based on constructs and assumptions from the Technology Adoption Model (TAM) and the UTAUT model. Although the studies highlight the applicability of UTAUT to provide theoretical perspectives thus justifying the choice of the model for the 
current research, their results cannot be generalised to address the context of educational technologies - e-learning by students. Besides, best practices in the cited literature did not cover e-learning. In fact, the current study provided a structured overview of best practices regarding the approach to e-learning by students. Ultimately, the relevant constructs of the UTAUT model in were used to inform the purpose of the current research. In fact, the core of the constructs of the UTAUT model is related directly to the objectives of the investigation in a way to inform them. The fundamental constructs of the UTAUT model are operationalized to provide insight on best practices, critical factors and inhibitors of e-learning in the current research as follows: performance expectancy (perceived usefulness and outcome expectations). The others are attitude, facilitating conditions (organisational elements, technical support, institutional issues). In addition to, effort expectancy (perceived ease of use, complexity, and ease of use) and social influence (subjective norms, social factors, and image). In summary, the research on best practices was underpinned by the UTAUT model. Ultimately, key objectives were identified to address the purpose of the study. These are presented next.

\subsection{Objectives of the study}

The purpose of the study was to determine the factors of the best practices of e-learning by undergraduate students at UKZN. The specific objectives of the study were:

1. To identify the best practices of e-learning by undergraduate students

2. To determine the critical factors that influence good practice of e-learning

3. To find out the inhibitors of best e-learning practices

\section{Literature review}

The lens used in reviewing literature was guided by the constructs of the adopted theoretical perspective, the purpose of the study and the UTAUT model.

\subsection{Best practices of e-learning}

Best practices of e-learning are viewed mostly from institutional positions. For instance, Csapó et al. (2012) highlighted technological issues when evaluating best practices as leverage for appropriate infrastructure and standards. Kahu (2013) and Abrami et al. (2012) underscore best practices that are based on support systems for both instructor and learners. Likewise, Chen, Hwang, and Wang (2012) evaluate the effectiveness of e-tools in an e-learning environment. The primary results highlighted factors such as willingness, usefulness, helpfulness as positively associated with the perceptions of the tools of elearning. Similarly, financial issues are reported to influence best practices of learning in a digital environment (Gedik, Hanci-Karademirci, Kursun, \& Cagiltay, 2012). It follows then that literature highlights existing knowledge of learning infrastructure, organisation, and process, learning content and financial issues in the context of best practices of elearning. However, user issues as they inform learning strategy remains unclear (Rossing, Miller, Cecil, \& Stamper, 2012; Huang, Lin, \& Huang, 2012). Also, a persistent omission in the literature on e-learning is examples of best practices in the use of e-learning by students (de-Marcos, Garcia-Lopez, \& Garcia-Cabot, 2016). As a result, the present study explored learning strategy of students as a lens to shed additional light on innovation, creativity and good practice of e-learning. In the current case, the key factors that contribute to the best e-learning practices of the students are determined. The aim was to 
improve user experiences by highlighting practical processes of learning strategy in an elearning environment.

Despite the seeming limitations of research on learning strategy and best practices from the perspectives of students, some pioneers provide a framing of what is available in the literature. After all, Fonseca et al. (2014) showed evidence of improved academic results based on the integration of augmented reality objects and tools in a project that involved the evaluation of the effect of 3D models on building and architecture students. The main conclusions indicate that the new digital media correlated with a motivation of students for improved academic performance. The implications of the findings reflected on a need to improve understanding of the content of digital media and the complexity of their use. Weichhart, Stary, and Appel (2018) investigated the support for learning management and self-organised learning processes often promoted in the progressive education research in the context of evolving digital learning environment practices that augment self-driven learning. The findings of the earlier mentioned researchers proposed an extension of current e-learning platforms by approaches that embody progressive education. Also, Noteborn, Dailey-Hebert, Carbonell, and Gijselaers (2014) recommended solutions for module coordinator to improve the potential impact of learning content on academic achievements and improved performance of students in a virtual learning environment. Some of the recommendations include content design and procedural knowledge. Whereas the focus of the study was from the perspectives of content developers and designers, the current study employed the lens of students. By extensions, Morgan (2014) showed an improvement in the academic skills of parents in the integration of digital media to learning materials. Ultimately, the researcher subjected the students to the same media and reported evidence of improved academic performance. Consider that a goal of the current study was to highlight the new developments, styles and approaches of students to e-learning to intending to improve the understanding of student practices.

In summary, the review of the literature indicates a best practices landscape that is not comprehensive or practical to identify, evaluate and promote best practice behaviour. The section also briefly highlighted the limitations of existing best practices in the context of e-learning. Ultimately, the research provided the necessary insights to best practices learning strategy.

\section{Methodology}

This study combined both a quantitative and qualitative approaches. Accordingly, the quantitative approach was more dominant based on the purpose of the study and the research questions. The qualitative methods helped to understand the patterns of user behaviour, validate quantitative data and for context-specific issues. Also, the methodological choices were to add scope and breadth to the research. For instance, Hussein (2009) and Venkatesh, Brown, and Bala (2013) argue that combining quantitative and qualitative approaches provide a sound method to neutralise the shortcomings of one approach by strengthening the advantages of the other. Also, Creswell $(2009,2013)$ provided a paradigmatic justification for combining quantitative and qualitative approaches to address the same research objectives of a single study.

A survey design was chosen in the conduct of the study. This design allowed the researcher to draw on a broad sample which is representative of the total population (Babbie, 1992). Similarly, a survey was deemed appropriate as a result of its specificity comprising data collection from undergraduate students drawn from a population using 
instruments (Melnyk, Page, Wu, \& Burns, 2012). Consequently, the research adopted a survey approach because it was the most prominent method used in previous related studies (Nawaz, 2013; Khan, \& Nawaz, 2013). The population of the study comprised the entire students $(5,000)$ of the School of Social Sciences at the two selected campuses of the University of KwaZulu-Natal (UKZN). There are four cognate disciplines in the school. These are; Culture, International and Public Affairs, Development and Society, and Social Change. All the undergraduate students of the School of Social Sciences in the two campuses were invited to participate in the online survey. The recruitment of participants was maximized by seeking the assistance of module coordinators, mentors, tutors, demonstrators, level advisors and class representatives. The link to complete the online survey was sent to all students' email accounts and social media pages. Eventually, 2,718 students completed the questionnaire and 15 respondents to the in-depth interviews. The reason for the relatively high response was due to the recruitment procedure that was initiated through faculty. Also, the use of response rate maximisation methods was employed to minimise to the minimum the potential for nonresponse error (Kristjansson, Sigfusson, Sigfusdottir, \& Allegrante, 2013; Fumagalli, Laurie, \& Lynn, 2013; Fowler, 2013). Additional procedures included data collection at appropriate schedules for the learners, motivation and ensuring that many students buy-in into the project. After all, the overriding purpose of the study was to characterise e-learning practices and improve the understanding of the e-learning experiences of the students. Consequently, the sample design focused a generation of rich data appropriate to address the purpose of the study and not to make a broad generalisation. Ethical procedures ensured that respondents were aged between 19 and 30+ years of age, and parental consent was unnecessary according to South African law. Consequently, participants signed the Informed Consent (IC) demonstrating an understanding of the purpose of research, benefits and associated risks of participation. Respondents who might suffer any risks were screened out by the researcher. Also, the nature of the research did not involve medical or student records, physical examination, and personal information. Furthermore, the project report did not include real names of any respondent and adhered to strict confidentiality. Finally, ethical clearances and approvals were received before the conduct of the study.

\subsection{Instruments}

The use of the survey questionnaire for data collection was in line with the quantitative approach used in this study. The design of the questionnaire and the constructs included in the survey was informed by the objectives, literature review (Gedik et al., 2012; Chen, Hwang, \& Wang, 2012), and the theoretical framework underpinning the study. Accordingly, four core constructs were used to frame the survey instruments. These were skills and competency; attitude; infrastructure; and support and innovation. The categorisation was aimed at capturing the standards, the critical factors and an understanding of the best practice of e-learning. Ultimately, each of the four categories was observed using a group of indicators. The indicators were adapted from the constructs of the UTAUT model and various previous related studies (Lee, Hsieh, \& Chen, 2013; Harsanto, 2014). The questionnaire was divided into sections A, and B. Section A required the respondents' demographic information. Section B contained the survey items. The two sections were further broken down into subdivisions based on the objectives of the study. The description of the parts was thus: Sub-division part 1: eLearning use behaviour, Part 2: Innovations in e-learning practices. Many of the question items were adapted from (Imamoglu, 2007; Lee, Lee, \& Seo, 2015). Part 3: Factors that influence e-learning practices. Part 4: Inhibitors. The earlier mentioned constructs included several measures. Thus, the measures operationalise and define the constructs 
included in the survey. For instance, skills and competency comprised perceived ease of use, complexity, ease of use, learner-centred approach. While, perceived usefulness and outcome expectations, negative feelings, positive feelings, beliefs, interest and subjective norms characterised, the factors that tested the attitude construct. Infrastructure was informed by measures such as social factors, image, perceived enjoyment, perceived satisfaction, benefits, organisational issues. Finally, support and innovation were framed by the following criteria: technical support, motivation and learning style, willingness (to try new approaches), technological elements. Also, the items in the survey questionnaire were rated on 4 points Likert scale with the following endpoints: 4-strongly agree, 1strongly disagree and two mid-points of 3-agree and 2-disagree. The methods of quantitative data analysis included descriptive, summary statistics and chi-square. Ultimately, the survey questionnaire consisted of 4 pages containing 40 items. The following sub-sections describe how the variables in the research were measured. Firstly, the quantitative strands are described.

\subsubsection{Measurement of skills and competency}

Skills and competency construct comprised eight indicators to assess the learners' skills and competency practices (see the section on instruments for the details of the measures). Meanwhile, the indicators adapted from Gray, Ryan, and Coulon (2004) and Samuel et al. (2004) include: The use of e-learning strengthens my abilities, I use the PC for work and play; I was comfortable using the PC and software applications before I took up elearning based modules. The others are: I can solve problems using computers; I can share ideas with others using digital tools; I can work effectively with others using technological tools. The others measured competency using the following items: I can write simple codes, algorithms and basic programming (Java, web and technical abilities) and I learn best by participation and contribution.

\subsubsection{Measurement of attitude}

The attitude characteristics construct was assessed to gain insights on the attitudes towards e-learning. The dimensions that informed the attitude construct are mentioned in the earlier section on instruments. Accordingly, the question stems included eight items such as e-Learning offers efficiency and time management; e-Learning reduces my financial burden; e-Learning ensures schedule flexibility. I enjoy using e-learning; I feel confident using e-learning; I believe that educational technologies enhance my learning experiences; e-Learning is useful in my classes. The items to complete measuring the critical factor of attitude to e-learning were adapted from Masrom, Zainon, and Rahiman (2008) and Paechter, Maier, and Macher (2010).

\subsubsection{Measurement of infrastructure}

The sources of measures for infrastructure construct are mentioned earlier. Moreover, 11 items covered the construct with the scales adapted from Chen, Hwang, and Wang (2012) and Joint Information Systems Committee (JISC, 2004). The scale items included: I am satisfied with my e-learning system experience; My use of e-learning gives me a right image; Students around me think the e-learning platforms are helpful; The design of the e-learning content and features stimulate learning. The other measures are: The support structures enhance diversity, equity and access; Assessment and feedback features are adequate; The e-learning infrastructure has excellent flexibility. Also, the access and 
quality of infrastructure are measured thus: It is easy to obtain; The e-learning tools are easy to use.

\subsubsection{Measurement of support and innovation}

This category included items to measure the critical factors for successful outcomes of elearning. The indicators involved the following: I can get technical support from the Information and Computer Services; Engaging guidelines to using the e-learning system would enable me to accomplish more on the platform quickly; The instructions to using the Moodle platform are easy for me; Peer support is positive leverage. Some of the others are: I try new and different things on the e-learning platform before anyone else I know; I try new things with e-learning without a fuss; I continuously try new things; When experiencing a new e-learning skill, I prefer someone to explain to me how to do it. Also, indicators included: When learning a new skill on Moodle, I prefer to watch someone else show me how to do it. I am concerned about doing well with e-learning. Birch and Burnett (2009) and Bolívar-Ramos, GarcíA-Morales, and GarcíA-SáNchez (2012) informed the choice of the next indicators: I look out for new e-learning experiences; I accept changes in how I use e-learning; I drive my e-learning agenda using social media-based interactions.

\subsubsection{Inhibitors}

The measurement of inhibitors was framed by barriers such as organisational, economic, hardware, software, support, pedagogical, psychological and skills approved by previous studies (Childs, Blenkinsopp, Hall, \& Walton, 2005; Liu, Chan, Hung, \& Lee, 2002). Some of the items that measured inhibitors comprised the following: There is a preference for traditional teaching; I have a lack of e-learning/technological confidence; There is little or no motivation for e-learning; Absence of collaborative platforms to share experiences. The items measuring inhibitors covered: A lack of domestication to meet needs; Negative perceptions; Lack of features to integrate multiple media contents and; Attitudinal issues.

\subsubsection{Interview schedule}

The research involved qualitative strands. Accordingly, the interview guide was informed by the preliminary findings from the pre-test of the survey questionnaire and contextspecific issues that emerged during the exploratory field data collection. In fact, the issues arising from the use of the survey tool informed the design of the interview guide. Consequently, background issues that required additional probing of respondents were retained in the interview schedule. The sample size for the interviews was drawn based on the pre-test exercise. The semi-structured interview schedule was thematically underpinned by the following constructs: skills and computing, attitude, infrastructure and support and innovation to provide significant insights on the requisite research questions seeking to unravel the best practices of e-learning and associated inhibitors. Accordingly, the interview schedule was divided into sections such as Pre-interview; Icebreakers; Use of terms/Notes; Competencies; e-Learning strategy; Critical factors; Inhibitors. Ultimately, the question stems included the following: How do you define elearning at UKZN? What are the essential features of e-learning to you? What is your rationale for adopting e-learning? What outcomes/expectations are you seeking? What incentives do you use to achieve your outcomes? What are the critical drivers of elearning for you? The other question items were: What indicators do you use to measures 
your approach to e-learning? Are any of these approaches highly specific to you (style, preferences)? Have your peers helped to shape your approach to e-learning? (How? When?) How do you monitor your e-learning practice/approach to progress? Content and document analysis methods were used for qualitative data. The next sections present the validity and reliability of analysis conducted and results of the data analysis. Finally, the presentations are guided by choice of methodological approach and the objectives of the research.

\subsection{Validity and reliability}

Two experts reviewed the instruments with research interests in e-learning. The experts' reviews helped to moderate and modify the survey tools. Moreover, the fact that most items in the survey questionnaire were adapted from previous related studies in part justified the validity of the instrument. Nevertheless, the survey questionnaire was pretested on forty Honours students from relevant School. After all, this category of students did not take part in the final study. A test-retest reliability method of two weeks interval was employed, and responses collected were subjected to Cronbach Alpha. The overall reliability of the questionnaire returned $\alpha=0.91$ which exceeded the minimum standard of 0.80 suggested for basic research (Wang \& Tang, 2003). The reliability of each construct showed that skill and competency $\mathrm{r}=0.71$; attitude $\mathrm{r}=0.74$; infrastructure $\mathrm{r}$ $=0.75$; support and innovation $\mathrm{r}=0.70$ and inhibitors $\mathrm{r}=0.69$. Thus, it was only after observing the data quality techniques mentioned above that further analysis was conducted.

\section{Data analysis and results}

Analysis of the responses from survey questionnaire and interviews was conducted in a way to highlight fundamental themes, contrast patterns and achieve data clustering. Furthermore, coding was executed to enable data to be analysed using categories, assumptions, and arguments based on the works of Braun and Clarke (2006) and Neuman and Robson (2012). In other words, thematic analysis is an approach for identifying, analysing and reporting themes within data. A justification of the choice of thematic analysis is because it can be employed within different theoretical perspectives - in this case, the UTAUT model. Also, the framework for the presentation of the results is informed by the methodological choices and the objectives of the study. It is noteworthy that even though both quantitative and qualitative methods are adopted, the dominant approach is the former. Accordingly, reporting the findings is framed by the results from the survey questionnaire and complemented by the conclusions of the survey interviews where appropriate. In other words, the results based on the methods are not presented exclusive of one another but instead employed an integrated model to aid the comprehension of the reader. In short, the adopted approach is to avoid redundancy. A further advantage of the procedure is to stimulate a vibrant synthesis where (and why) the results are similar or dissimilar among the methods. Johnson and Onwuegbuzie (2004) and Fetters, Curry, and Creswell (2013) recommend the incorporation of the results when reporting rather than splitting them into quantitative and qualitative buckets. After all, Onwuegbuzie and Leech (2005) refer to the splitting as a false dichotomy. Ultimately, the demographics table below shows that there was a total number of 2,718 respondents, with the respondents made up of 1,809 males and 909 females from the PMB and HC campuses of UKZN. The respondents are 2,718 respondents. The highest number of interviewees is from the discipline of International \& Public Affairs (47.9\%). All other demographic details of respondents can be found in Table 1 on student demographics. 
Table 1

Student demographics $(\mathrm{n}=2718)$

\begin{tabular}{lll}
\hline Demographics & Frequency & Percentage \\
\hline Clusters/Disciplines & & \\
Culture & 601 & 22.1 \\
Development & 446 & 16.4 \\
International \& Public Affairs & 1301 & 47.9 \\
Society \& Social Change & 370 & 13.6 \\
Total & $\mathbf{2 , 7 1 8}$ & $\mathbf{1 0 0 . 0}$ \\
Campus & & \\
Howard (HC) & 1,738 & 64 \\
Pietermaritzburg (PMB) & 980 & 36 \\
Total & $\mathbf{2 , 7 1 8}$ & $\mathbf{1 0 0}$ \\
Female & 1,809 & 66.6 \\
Male & 909 & 33.4 \\
Total & $\mathbf{2 , 7 1 8}$ & $\mathbf{1 0 0 . 0}$ \\
Age & & \\
19-22 years & 902 & $\mathbf{3 3 . 1}$ \\
23-26 years & 883 & $\mathbf{3 2 . 5}$ \\
27-30 years & 779 & $\mathbf{2 8 . 7}$ \\
31 years and above & 154 & $\mathbf{5 . 7}$ \\
Total & $\mathbf{2 , 7 1 8}$ & $\mathbf{1 0 0 . 0}$ \\
\hline
\end{tabular}

\subsection{Best practices of e-learning}

Respondents were also given the option to write out new styles, improvements and problem-solving approaches and solutions to their e-learning tasks for analysis. The respondents had the privilege of indicating various practices and behaviour in their elearning experiences. The comparison of the survey questionnaire and interview responses provides a better understanding of e-learning practices. Accordingly, the source of data presented in Table 2 is the participant responses from the survey questionnaire.

The Table 2 shows that the best practices include collaborative behaviour and activities and students 'self-creation of support group - forums. The others are the sharing of real life situations, e-learning experiences and activities and the domestication of the communication features available on the e-learning platform by using local South African languages for interacting with one another. To put it succinctly, the operationalisation of best practices of e-learning in the current research refers to creativity, innovation, change, improvement, problem-solving and a set of standards and guidelines adopted for efficient use of the e-learning platform. Consequently, best practice behaviour includes immersion, self-evaluation, control and personalised learning. It is common for immersion to be reported regarding the user's e-learning games and Virtual Worlds whereas there is evidence of similar results in the context of e-learning tasks in the current study.

By extension, the qualitative strand of the research covered the objective that addressed determining innovations in the e-learning use behaviour of the students. In short, qualitative data were collected using in-depth interviews with 15 students. Accordingly, the analysis of the qualitative strand in the current study involved the use of researcher judgment to determine crucial themes within data. 
Table 2

Best practices of e-learning

\begin{tabular}{|c|c|c|c|}
\hline $\mathbf{S} / \mathbf{N}$ & Practices & Frequency & $\%$ \\
\hline 1 & $\begin{array}{l}\text { Full immersion interactivity levels using customised } \\
\text { audio/video, multimedia, and simulation }\end{array}$ & 661 & 24.3 \\
\hline 2 & $\begin{array}{l}\text { Students share real life scenarios, experiences, stories, } \\
\text { graphics, visuals \& games to engage one another }\end{array}$ & 883 & 32.5 \\
\hline 3 & $\begin{array}{l}\text { Students' creation of multiple forums such as online } \\
\text { discussions \& Facebook pages to ask questions, share } \\
\text { experiences and interact }\end{array}$ & 1019 & 37.5 \\
\hline 4 & $\begin{array}{l}\text { Domestication - students use local languages (Zulu, } \\
\text { Afrikaans, Xhosa \& Venda) to communicate using the } \\
\text { learning system and social media }\end{array}$ & 771 & 28.4 \\
\hline 5 & Students' self-created e-learning support in small groups & 507 & 18.7 \\
\hline 6 & Embedment of e-learning into social contexts of students & 402 & 14.8 \\
\hline 7 & $\begin{array}{l}\text { Students took ownership of stored resources on their } \\
\text { storage facility on the learning system }\end{array}$ & 115 & 4.2 \\
\hline 8 & Self-evaluation & 556 & 20.5 \\
\hline 9 & $\begin{array}{l}\text { Empowerment of students - spontaneity of learning via } \\
\text { Blackberry tools (BBMs) }\end{array}$ & 298 & 11 \\
\hline 10 & Collaborative activities & 1142 & 42 \\
\hline 11 & $\begin{array}{l}\text { Control - student can test their knowledge at their own } \\
\text { time }\end{array}$ & 115 & 4.2 \\
\hline 12 & Personalized learning & 392 & 14.4 \\
\hline
\end{tabular}

The determination of prevalence involved flexibility and refinements of themes and sub themes to arrive at overall themes. For instance, critical themes identified in Table 3 such as awareness, fascination with innovation, immersion, time-saving, ease of use, social contexts of practices, interactivity and best practices. And themes like individuality, novelty, faculty/peer influence and sharing of user experiences collectively represent fundamental elements of the way the students characterised best practice behaviour in their use of e-learning. For example, the flexibility of the adopted thematic analysis allowed the researcher to count how many different interviewees articulated the same theme across the individual interviews, and this approach was consistently used for qualitative analysis in the current research. In short, the analysis involved observed patterns of meanings, related matters and recursive processes between the data set, coded extracts and the production of the analysis of data. The phase 1 of analysis incorporated immersion in the data by repeated reading to search for meanings and patterns and note taking. Ultimately, verbal data are transcribed into written form based on the convention that it is practically suitable to address the purpose of the analysis (Edwards, 1993). Consider that the convention stipulates that the transcript retains a true representation of the verbal account. The transcription, close reading, interpretation and analysis are conducted by the researcher. Phase 2 involved a generation of initial codes manually by identifying semantic contents of interest and elements of raw data. For instance, codes that apply to brief segments of data in Table 3 include 1. Think. 2. Too much information. 3. Talk about vital issues. 4. Observation of step by step guide, to cite a few. Also, coding is theory-driven based on the adopted theoretical perspective and the research questions of the study. Consequently, the coding provides a thematic map for the conceptualisation 
of the patterns of data and their relationships. The following phase starts with a broad list of different codes across the data set, sorting into potential themes and a collation of relevant coded extracts of data within concise themes. The visual representation approach (tables and mind mapping) is used in the sorting of codes to arrive at collections of potential themes and sub themes. The next phase is a reviewing and refinement of themes. The analysis procedure ensured that themes captured adequately the intricacies of coded data by validating individual themes in relation to the data set and ultimately whether the themes represent the meanings generated in the data set or re-coding was necessary. Defining and naming of themes are carried out in the final phase. The procedure organised data extracts for each clearly identified theme into coherent and internally consistent accounts with requisite narrative (Braun \& Clarke, 2006). Finally, extracts are embedded in the report of the current study to provide an analytic narrative with compelling illustrations about the interview data to make arguments to cover the research questions of the study. Thus, some of the significant statements and emerging themes obtained are presented in Table 3.

Table 3

Qualitative data on best practices

\begin{tabular}{|c|c|}
\hline Key statement & Emerging theme \\
\hline $\begin{array}{l}\text { "I think there's so much information out there using e-learning } \\
\text { that I need to improve how to access it efficiently." }\end{array}$ & $\begin{array}{l}\text { Awareness of potentials of e-learning \& } \\
\text { necessity of skills }\end{array}$ \\
\hline $\begin{array}{l}\text { "Innovation and new ideas in my e-learning practices are vital } \\
\text { issues to me." }\end{array}$ & Students like innovation \\
\hline $\begin{array}{l}\text { "I observe that the step-by-step guide to using the e-learning } \\
\text { service provided on walls of the computer LANs save me time } \\
\text { and enhance ease of use." }\end{array}$ & $\begin{array}{l}\text { e-learning innovation saves time and is easy to } \\
\text { use }\end{array}$ \\
\hline $\begin{array}{l}\text { "The ways that I use e-learning in my academic and social life } \\
\text { is vital." }\end{array}$ & Social context of practice \\
\hline $\begin{array}{l}\text { "I spend a lot of my time either chatting with course mates, } \\
\text { tutors and module coordinators using platforms available on } \\
\text { the learning system." } \\
\text { "I like the informal nature of chatting with my class mates in } \\
\text { the learning space devoid of formalities." }\end{array}$ & Social interactions/conversational \\
\hline $\begin{array}{l}\text { "I enjoy playing back videos, visiting hyperlinks provided and } \\
\text { the simulation activities." } \\
\text { "The e-learning environment and links it provides seem like } \\
\text { real-life solutions to my needs for specific modules." }\end{array}$ & Immersion activities \\
\hline $\begin{array}{l}\text { "I am conscious of the details of what works for me while } \\
\text { using e-learning to improve my studies." }\end{array}$ & Best practices versus practices \\
\hline $\begin{array}{l}\text { "The more I use e-learning, the more I apply it to other new } \\
\text { areas such as academic writing and conversational skills with } \\
\text { my peers." }\end{array}$ & Novelty in applications scope of e-learning \\
\hline $\begin{array}{l}\text { "I use my model in my use of the Moodle learning platform by } \\
\text { figuring out what worked well and what didn't I discard and } \\
\text { move on." }\end{array}$ & Individuality \\
\hline $\begin{array}{l}\text { "I use e-learning for at least } 3 \text { hours daily mostly seeking } \\
\text { advice and opinions from module coordinator, mentors, peers } \\
\text { and group members in class assignments." }\end{array}$ & Faculty and peer exchanges \\
\hline $\begin{array}{l}\text { "The experiences of friends in my class lead me to use e- } \\
\text { learning tools to improve my reading and exam preparation." }\end{array}$ & Exchange of user experiences a \\
\hline
\end{tabular}


An in-depth analysis of qualitative data shows that a clear and efficient communication from instructors, tutors, mentors and peers (fellow students) associate with innovation and creativity in the use of e-learning by the students. The finding is consistent with that of the quantitative strands supporting collaborative behaviour and activities and self-created support structures as critical factors. In fact, rich immersion experiences and individual/personal learning prospects are the reported drivers of elearning. The results corroborate those from the quantitative analysis. The additional light shed by the qualitative strands is the emphasis on social landscape of the student and the less formal exchanges in the domain of the students. The qualitative results provide meaningful insights for evolving a theory of e-learning practices by students considering social and community factors that the results highlight. Specifically, the results support a generative approach to e-learning by the students based on the indicators that learners can generate a lot of data in their communication that they understand. This understanding is central to developing an effective instruction for students to use e-learning. The next section provides the findings of the factors of good practice of e-learning.

\subsection{Factors of best e-learning practices}

Table 4 presents the results of the analysis of the fundamental factors that influence innovation in e-learning practice.

Table 4

Rotated component matrix

\begin{tabular}{lccccc}
\hline & $\begin{array}{c}\text { Effort } \\
\text { expectancy }\end{array}$ & Attitude & $\begin{array}{c}\text { Social } \\
\text { influence }\end{array}$ & $\begin{array}{c}\text { Facilitating } \\
\text { conditions }\end{array}$ & $\begin{array}{c}\text { Performance } \\
\text { expectancy }\end{array}$ \\
\hline Perceived ease of use & $\mathbf{. 8 6 1}$ & -.122 & .019 & .113 & .300 \\
Complexity & $\mathbf{. 8 3 7}$ & -.127 & .122 & -.217 & .234 \\
Ease of use & $\mathbf{. 8 2 9}$ & .031 & .334 & .014 & .189 \\
Learner-centred approach & .235 & .055 & -.136 & .335 & .091 \\
Negative feelings & .126 & $\mathbf{. 1 5}$ & .286 & .105 & .001 \\
Positive feelings & .173 & $\mathbf{. 7 9 7}$ & .180 & .135 & .143 \\
Beliefs & .136 & $\mathbf{. 1 1 6}$ & -.127 & .103 & .215 \\
Interest & .227 & .237 & .319 & -.203 & .171 \\
Subjective norm & .171 & .116 & $\mathbf{. 8 4 7}$ & .071 & .055 \\
Social factors & .032 & .197 & $\mathbf{. 8 7 6}$ & .095 & -.190 \\
Image & .034 & .302 & $\mathbf{. 8 5 5}$ & .180 & .033 \\
Perceived enjoyment & .202 & .117 & .112 & .061 & .127 \\
Perceived satisfaction & .280 & .186 & .291 & .144 & .331 \\
Benefits & .010 & .149 & .071 & .054 & .118 \\
Organizational issues & .305 & .190 & .092 &. $\mathbf{7 5 0}$ & -.197 \\
Technical support & .136 & .097 & .121 & $\mathbf{. 8 1 8}$ & .012 \\
Institutional support & .102 & .272 & .242 &. $\mathbf{8 0 1}$ & .093 \\
Motivation & .315 & .296 & -.024 & .321 & .245 \\
Learning style & .014 & .119 & .218 & .330 & .332 \\
Willingness to try new approaches & .083 & .245 & .105 & .217 & .114 \\
Technological elements & .041 & .126 & .097 & .293 & .345 \\
Perceived usefulness & .342 & .115 & .182 & .098 &. $\mathbf{6 2 7}$ \\
Outcome expectations & .097 & .178 & .327 & .083 &. $\mathbf{5 5 8}$ \\
Cronbach's $\alpha$ & 0.9281 & 0.8901 & 0.9010 & 0.8411 & 0.7429 \\
Eigenvalue & 8.971 & 4.360 & 2.249 & 1.526 & 1.604 \\
\% variance & 18.531 & 13.391 & 7.980 & 7.732 & 7.518 \\
Cumm. \% variance & 23.630 & 41.807 & 55.281 & 63.518 & 70.822 \\
\hline
\end{tabular}


Table 4 reveals the rotated component matrix with their corresponding loadings extracted based on relevant constructs (see values in bold text). The key output of the principal component analysis (PCA) known as the rotated component matrix contains the estimates of correlations between each of the variables and the estimated component. The method of analysis was considered appropriate based on studies such as Osborne and Costello (2009) and Beavers et al. (2013). Also, the exploratory factor analysis indicates that twenty-three out of a total of twenty-nine variables loaded on five distinct constructs. In other words, six variables were dropped off as a result of cross loading. The twentynine variables were drawn from the adopted theoretical framework (UTAUT model) and related literature (such as Dhir, Chen, \& Nieminen, 2016; Capece \& Campisi, 2013; Puri, 2012). Furthermore, the retained factors explained $70.8 \%$ of the variance in the data set. Also, the termination rate for the loadings was 04. Finally, a Cronbach's Alpha $\alpha>0.5$ for the factors suggest good reliability values based on Dunn, Baguley, and Brunsden (2014)

The evaluation of the criticality levels of the factors of best e-learning practices (using highest explained variance) by the students is the following: effort expectancy $(18.5 \%)$, attitude $(13.4 \%)$, social influence $(7.9 \%)$, facilitating conditions $(7.7 \%)$ and performance expectancy $(7.6 \%)$. Thus, the rotated matrix shows that the most critical factor is effort expectancy. The variable involves elements such as perceived ease of use, complexity, and ease of use of e-learning. Meanwhile, three variables load on the attitude factor to account for $13.4 \%$ of the total variance. Thus, the second crucial variable of best e-learning practice is the attitude. Put simply, negative, positive feelings and beliefs about e-learning are concerned with the evolution of best practices of e-learning by the students.

\subsection{Inhibitors of best e-learning practices}

The third research question found out the inhibiting factors of good e-learning practices of the students using mean rank values. A list of options was made available for respondents to identify inhibiting factors to their participatory culture, good practice and a sharing of best practices of e-learning. The factors were drawn from existing literature (Hustad \& Arntzen, 2013; Isabirye \& Dlodlo, 2014; Cox, 2013; Marshall, 2012). Meanwhile, the results of the analysis are presented in Table 5.

The analysis of the findings regarding the inhibitors in Table 5 shows that these include conflict with orthodox learning practices (mean rank of 19.72) and ignorance of resources available on the learning platform (mean rank of 15.08). Also, the analysis reveals that the culture of individuality over shared experiences (mean rank of 13.5) and motivational issues (11.61) are fundamental inhibitors. The chi-square value is 768.332 and a p-value of 0.000 . The full details of the mean values of the other inhibitors are available in Table 5. Based on the paradigmatic and methodological choices of the research, the third research question was addressed by quantitative and qualitative aspects. Thus, a comparison of data shows qualitative data complementing the quantitative findings presented in Table 5. For instance, the results of the interview analysis show a tricky and time-consuming process of resources' use and an ignorance of other students' needs for best practices of e-learning. Some of the interview responses are below:

"I often observe that I have options in my approach to e-learning to achieve my goals best, but I never thought of sharing with others or taking to someone's practice."

"There are very limited spaces for students to identify or share best practices of elearning hence I approach this in my little way." 
"I do not see the fuss about e-learning, my style of use and related issues as I am accustomed to my traditional learning and associated culture which are fine with me."

"Sometimes I just see e-learning as another hurdle for the student to cross over, and it takes time, too."

Table 5

Inhibitors of innovative practices $(\mathrm{N}=2718)$

\begin{tabular}{|c|c|c|c|}
\hline $\mathbf{S} / \mathbf{N}$ & Inhibitor & Frequency & Mean Rank \\
\hline 1 & $\begin{array}{l}\text { Conflict with orthodox learning } \\
\text { practices }\end{array}$ & 1235 & 19.72 \\
\hline 2 & Ignorance of e-learning resources & 1003 & 15.08 \\
\hline 3 & $\begin{array}{l}\text { Culture of individual over shared } \\
\text { experiences }\end{array}$ & 990 & 13.5 \\
\hline 4 & Motivational problems & 920 & 11.61 \\
\hline 5 & Lack of resources & 902 & 9.95 \\
\hline 6 & $\begin{array}{l}\text { Difficulty in identifying and using } \\
\text { best practices }\end{array}$ & 900 & 9.11 \\
\hline 7 & $\begin{array}{l}\text { Difficulty to understand e-learning } \\
\text { tools and features }\end{array}$ & 894 & 6.68 \\
\hline 8 & $\begin{array}{l}\text { Lack of demonstration of positive } \\
\text { impact of e-learning }\end{array}$ & 801 & 4.02 \\
\hline 9 & Negative perceptions & 794 & 3.67 \\
\hline 10 & Non-integrated mixed media & 675 & 3.22 \\
\hline 11 & $\begin{array}{l}\text { Limited platforms to share best } \\
\text { practices }\end{array}$ & 650 & 2.67 \\
\hline 12 & $\begin{array}{l}\text { The learning system not seen as } \\
\text { core to learning }\end{array}$ & 450 & 2.12 \\
\hline 13 & Students' requirements not met & 400 & 1.90 \\
\hline
\end{tabular}

\section{Discussion of findings}

The key results indicate that the characterisation of e-learning practices of the students is social, cultural, personalised and collaborative. The key results report students' selfcreated support structures and immersion, self-evaluation, control, personalised learning and collaborative work are best practices in the e-learning experiences of the users. The mapping of the best practices presented above support the learning of the students. The best approaches do not rely on institutional support structures for the students but make complex issues easy to understand and meaningful within social media networks of students. The results mean that the students have a direct social contact with one another in the orientation on the use of e-learning. Meanwhile, students bring themselves up to speed on good practice to maximise the use of the system. In fact, the best practices of elearning have solid foundations in the social landscape and strong relationships with the students to improve their e-learning experiences. The findings are consistent with McGee and Reis (2012) who report social structures and fabrics, individuality, variability and flexibility in the best practices of blended courses. Even though social structures are 
critical to best possible e-learning experiences, doing so without guidance may not augur well - leading to negative experiences and the transfer of mistakes into practice and a possible development of fixations. The research provides evidence that social processes of the students are fundamental components of best practices of e-learning experiences. The findings explain a need for the institution to benefit from inflows and outflows of elearning practices of the students and guidance as to how the social structures can be engaged. Also, there is evidence of immersed individuals demonstrating social comfort and presence in the e-learning environment just as Faizi (2018) affirmed immersion behaviour in the landscape of Web 2.0 tools. Another best approach was to evolve a domestication of the e-learning environment to suit South African context using local dialects native to the students other than English. The best practices adopted by the students are aligned to local and cultural perspectives, ownership and the establishment of interactions with groups of students. Meanwhile, the generalisation of the results is limited since the sample design aims at generativity (Hibbert, Sillince, Diefenbach, \& Cunliffe, 2014). As a result of these best practices, the current research outlines a framework for students to approach e-learning use such as alignment to South African contexts, student capacity building and establishment of student forums and platforms for interactions using local South African languages for communication other than English and Afrikaans. In other words, e-learning and Moodle training should be driven by the priorities of the individual students. For example by improving on existing approaches of posting guidelines to students in a way to drive pedagogical innovation in the approach to e-learning and reverse shortcomings. Instead, the proposed framework should be tasked to build the capacity of students by systematic interactions rather than institutional and parallel systems that do not serve the students.

Likewise, good practice of the students includes the creation of Web links to selfcreated Facebook and Twitter pages made available on the e-learning system. Perhaps, the most noteworthy practice is the self-creation of small groups of students to engage and share experiences with one another in the e-learning space. The primary results suggest that social features on the e-learning platform support the adoption of the technology by students for educational contexts. Also, the fundamental results show that students let the e-learning system do its work to support them and need to be aware of best practices in their approaches and user experiences. However, the identified best practices seem to be at the behest of the students whereas the implementation of elearning should have established an efficient process of internal benchmarking to identify, share and use e-learning best practices (Ahn, Brusilovsky, \& Han, 2015).

Perhaps, a modelling of the right practice of e-learning through intervention activities, interactions, and peer engagements may provide effective avenues to launch diffusion further. Indeed, there is a dissonance between e-learning practice, identification by the students and self-reliance. Similarly, Reilly, Vandenhouten, Gallagher-Lepak, and Ralston-Berg (2012) advocate a community of practice approach to the practice of elearning by incorporating new e-learning skills, knowledge, and attitudes. Whereas technology enthusiasts are quick to advance tools such as e-learning, it is significant to motivate students for a personal need for identification of good practice and behaviour (Abrami et al., 2012). In fact, sufficient diffusion of e-learning best practices and exchange among students should be given attention and encouraged to enhance any strategic value of e-learning systems (Decker et al., 2013). Moreover, there should be a transformation of practices of e-learning as the phenomenon continues to evolve using the lens of students (Mulwa et al., 2012).

The most significant factors of best practices of e-learning by students are perceived ease of use, complexity, and ease of use. The results mean that the conditions 
such as guidelines and instructions support the practice level of e-learning by informing the students' perceptions of the ease of use of the learning platform and complexity. It follows then that new things to consider as a result of the findings are the inclusion of students in the design of guidelines and instructions to approach e-learning to increase ownership and investment of best practices. After all, previous studies call for an improved understanding of the factors by user groups such as students (Mohammadyari \& Singh, 2015; Keengwe, Onchwari, \& Agamba, 2014). Accordingly, the other major factors associated with best practices of e-learning include negative, positive feelings and beliefs, subjective norm, social factors and image. Ultimately, the least important factor regarding the proper practice of e-learning is perceived usefulness and outcome expectations whereas, perceived usefulness and perceived ease of use are well reported in the adoption of technology literature as the most critical (Lomas et al., 2013). The implications of the results of the current research are that perceived ease of use, complexity, and ease of use (effort expectancy) are important on individual students' practice level in the context of e-learning. Many students particularly care about their individual needs in their approach to using the e-learning system. In other words, individual students' e-learning practice is affected by how easy the service is to use. It seems that the ease of use is a platform for new e-learning skills and knowledge to foster. Also, beliefs, positive and negative attitudes are essential to the use of e-learning. Fortunately, Hassad (2013) found a correlation between the level of attitude towards the use of technology and determination of the degree of behaviourist teaching practice. Contrarily, Stokke, Olsen, Espehaug, and Nortvedt (2014) report that even though nurses have a positive attitude towards evidence-based practices they engage in it to a much lesser extent. The reason for the counter findings may be because the latter focused professional nurses and not undergraduate students in the context of e-learning. The fundamental findings regarding the primary factors of best practices of e-learning suggest that good practice approaches may increase the rates of use, satisfaction, motivation and improve the experiences of students with e-learning. There is the need to improve the ease of use of e-learning and the demands of complexity they make on the users. Further results reveal that focus on best practices should include subjective norms, image, social networking, dialogue and social factors based on students' work and experiences with elearning practice. Put simply, the implication of the results is that the managers of elearning at UKZN should bear in mind and better understand how the key factors impact e-learning innovations. Theoretically, the UTAUT model, its core constructs, assumptions, and arguments were used to inform the objectives and purpose of the research. Accordingly, the model added scope and breadth to the study. Consider that there is limited use of UTAUT to explain best practices and the study demonstrated the use of the model in this context. Although the aim was not to evaluate UTAUT, it was to provide a broader exploration of the model based on the quantitative and qualitative data. The results suggest a suitability of the UTAUT in the context of research on best practices of e-learning.

Finally, the primary results on the inhibitors of good practice highlight a tricky conflict between traditional and e-learning practices for some students. For example, the significant results regarding research question three show that students find it difficult to identify and share best practices (see Table 5). Meanwhile, best practices interventions are expected to improve the e-learning experiences of students. Consequently, the difficulty diminishes the potential for good practice. Also, there is evidence of obstacles such as ignorance of e-learning needs and resources, individual expertise over collaborative learning and knowledge sharing for good practice. Further key results regarding inhibitors show factors such as weak demonstration of an impact of the use of e-learning on academic performance and lack of tools and resources to maximise e- 
learning skills and practices among the students. Moreover, Stepanyan, Littlejohn, and Margaryan (2013) emphasise that for e-learning to be sustained, there is a need to address challenges such as lack of resources, conflicting beliefs and practices and social contexts of learners. E-learning acceptance and use on its own will not lead to accessible and efficient e-learning practices without a firm understanding of the challenges to learning strategy. However, the approach to a good practice depends also on the view of students of e-learning and their roles within that space. Consequently, the opinion of the students is crucial to the formation of a learning strategy. Unfortunately, there is limited research on learning strategy and associated obstacles using the lens of students (Donker et al., 2014). Thus, the last research question of the study tried to address some of these concerns. The next section presents the conclusions of the survey.

\section{Conclusion}

The research is needed and essential to strengthen and improve the understanding of best practices by which students approach e-learning which suffers from a shortage of innovation, creativity and diffusion of best practices. The study analyses and describes the different best practices in the e-learning experiences and presents an overview of the factors that affect the practice level of e-learning of students. The study identified insights and reflections of good practice and the elements of a learning strategy from the perspective of students to contribute to an understanding of the role of user approach to elearning. For instance, it is best practice to domesticate e-learning to suit local South African contexts, student self-created support groups to share new skills, approaches, knowledge, and experiences. The study outlines initiatives to inform the best practices of students such as individual priorities, ownership, cultural contexts and capacity building of students to support themselves using South African languages as means of communication. Also, the research finds a need for focus on changes, alterations and new ideas no matter how slight or minute to improve the sound practice of e-learning by students. It follows then that the uptake of e-learning and best practices must be well understood. Consequently, the research presented the criticality levels of each of the following factors in the context of best practices of e-learning: perceived ease of use, complexity, and ease of use, attitude, and beliefs. The other factors are subjective norms, social factors, and image, organisational and technical support. Lastly, the research highlighted the relevance of factors such as perceived usefulness and outcome expectations to assist good practice and processes. In short, the deployment of e-learning systems is not just enough. Ultimately, the takeaway is that communication about best practices' interventions should be systematically integrated into the social structures and processes of students' e-learning experiences. The contribution discusses best practice approaches that are user-friendly regarding rules and procedures to stimulate the creativity and innovations of the users further. It would appear that the best practices assist in the appropriation of the e-learning tools by the students. However, the list of best practices provided in the current research is not exhaustive as e-learning continues to mature and users adapt to the phenomenon. It is expected that analytical results from the research have the potentials to enhance e-learning experiences of the students. Nevertheless, the research is limited as a result of methodological choices and the focus on students only. Besides, future studies may employ multi-methods of data collection and Structural Equation Modeling to reveal complex relationships between the main factors of best practice behaviour. 


\section{References}

Abrami, P. C., Bernard, R. M., Bures, E. M., Borokhovski, E., \& Tamim, R. M. (2012). Interaction in distance education and online learning: Using evidence and theory to improve practice. In L. Moller \& J. B. Huett (Eds.), The Next Generation of Distance Education (pp. 49-69). Boston, MA: Springer.

Ahn, J., Brusilovsky, P., \& Han, S. (2015, March). Personalized search: reconsidering the value of open user models. In Proceedings of the 20th International Conference on Intelligent User Interfaces (pp. 202-212). ACM.

Al-Qahtani, A. A. Y., \& Higgins, S. E. (2013). Effects of traditional, blended and elearning on students' achievement in higher education. Journal of Computer Assisted Learning, 29(3), 220-234.

Alhomod, S. M., \& Shafi, M. M. (2012). Best practices in E government: A review of some Innovative models proposed in different countries. International Journal of Electrical \& Computer Sciences, 12(1), 1-6.

Aziz, S. A., \& Idris, K. M. (2016). E-Taxation: The attitude and intention to use technology in Malaysia. In Proceedings of the International Conference on Accounting Studies (ICAS). Langkawi, Kedah, Malaysia.

Babbie, E. (1992). The practice of social research (6th ed.). Belmont, CA: Wadsworth Cengage Learning.

Bazhenov, R. I., \& Luchaninov, D. V. (2014). Use of blended learning elements for formation of a humanitarian student's creative initiative at learning modern information technologies. Life Science Journal, 11(11s), 371-374

Beavers, A. S., Lounsbury, J. W., Richards, J. K., Huck, S. W., Skolits, G. J., \& Esquivel, S. L. (2013). Practical considerations for using exploratory factor analysis in educational research. Practical Assessment, Research \& Evaluation, 18: 6.

Bell, B. S., \& Federman, J. E. (2013). E-learning in postsecondary education. The Future of Children, 23(1), 165-185.

Birch, D., \& Burnett, B. (2009). Bringing academics on board: Encouraging institutionwide diffusion of e-learning environments. Australasian Journal of Educational Technology, 25(1), 117-134.

Bocconi, S., Kampylis, P. G., \& Punie, Y. (2012). Innovating learning: Key elements for developing creative classrooms in Europe. Luxembourg: Publications Office of the European Union.

Bolívar-Ramos, M. T., GarcíA-Morales, V. J., \& GarcíA-SáNchez, E. (2012). Technological distinctive competencies and organizational learning: Effects on organizational innovation to improve firm performance. Journal of Engineering and Technology Management, 29(3), 331-357.

Braun, V., \& Clarke, V. (2006). Using thematic analysis in psychology. Qualitative Research in Psychology, 3(2), 77-101.

Capece, G., \& Campisi, D. (2013). User satisfaction affecting the acceptance of an elearning platform as a mean for the development of the human capital. Behaviour \& Information Technology, 32(4), 335-343.

Chen, Y. C., Hwang, R. H., \& Wang, C. Y. (2012). Development and evaluation of a Web 2.0 annotation system as a learning tool in an e-learning environment. Computers \& Education, 58(4), 1094-1105.

Childs, S., Blenkinsopp, E., Hall, A., \& Walton, G. (2005). Effective e-learning for health professionals and students-barriers and their solutions. A systematic review of the literature-findings from the HeXL project. Health Information and Libraries Journal, 22(s2), 20-32.

Cox, M. J. (2013). Formal to informal learning with IT: Research challenges and issues for e-learning. Journal of computer assisted learning, 29(1), 85-105. 
Creswell, J. W. (2009). Research design: Qualitative, quantitative, and mixed methods approaches (3rd ed.). SAGE Publications.

Creswell, J. W. (2013). Research design: Qualitative, quantitative, and mixed methods approaches (4th ed.). Sage Publications.

Csapó, B., Ainley, J., Bennett, R. E., Latour, T., \& Law, N. (2012). Technological issues for computer-based assessment. In P. Griffin, B. McGaw, \& E. Care (Eds.), Assessment and Teaching of 21st Century Skills (pp. 143-230). Netherlands: Springer.

Decker, S., Fey, M., Sideras, S., Caballero, S., Boese, T., Franklin, A. E., \& Borum, J. C. (2013). Standards of best practice: Simulation standard VI: The debriefing process. Clinical Simulation in Nursing, 9(6), S26-S29.

de-Marcos, L., Garcia-Lopez, E., \& Garcia-Cabot, A. (2016). On the effectiveness of game-like and social approaches in learning: Comparing educational gaming, gamification \& social networking. Computers \& Education, 95, 99-113.

Dhir, A., Chen, S., \& Nieminen, M. (2016). The effects of demographics, technology accessibility, and unwillingness to communicate in predicting internet gratifications and heavy internet use among adolescents. Social Science Computer Review, 34(3), 278-297.

Divaharan, S., \& Lim, C. P. (2010). Secondary school socio-cultural context influencing ICT integration: A case study approach. Australasian Journal of Educational Technology, 26(6), 741-763.

Divaharan, S., Lim, W. Y., \& Tan, S. C. (2011). Walk the talk: Immersing pre-service teachers in the learning of ICT tools for knowledge creation. Australasian Journal of Educational Technology, 27(8), 1304-1318.

Donker, A. S., De Boer, H., Kostons, D., van Ewijk, C. D., \& Van der Werf, M. P. C. (2014). Effectiveness of learning strategy instruction on academic performance: A meta-analysis. Educational Research Review, 11, 1-26.

Dunn, T. J., Baguley, T., \& Brunsden, V. (2014). From alpha to omega: A practical solution to the pervasive problem of internal consistency estimation. British Journal of Psychology, 105(3), 399-412.

Edmonds, R. (2006). Best practices for e-learning. In U. D. Ehlers \& J. M. Pawlowski (Eds.), Handbook on Quality and Standardisation in E-Learning (pp. 485-500). Berlin, Heidelberg: Springer.

Edwards, J. A. (1993). Principles and contrasting systems of discourse transcription. In J. A. Edwards \& M. D. Lampert (Eds.), Talking Data: Transcription and Coding in Discourse Research (pp. 3-31). Hillsdale, NJ: Lawrence Erlbaum Associates.

Erichsen, E. R., \& Salajan, F. D. (2014). A comparative analysis of e-learning policy formulation in the European Union and the United States: Discursive convergence and divergence. Comparative Education Review, 58(1), 135-165.

Faizi, R. (2018). Moroccan higher education students' and teachers' perceptions towards using Web 2.0 technologies in language learning and teaching. Knowledge Management \& E-Learning (KM\&EL), 10(1), 86-96.

Fath-Allah, A., Cheikhi, L., Al-Qutaish, R. E., \& Idri, A. (2014). E-government portals best practices: A comprehensive survey. Electronic Government, An International Journal, 11(1/2), 101-132.

Fetters, M. D., Curry, L. A., \& Creswell, J. W. (2013). Achieving integration in mixed methods designs-Principles and practices. Health Services Research, 48(6pt2), 2134-2156.

Fonseca, D., Martí, N., Redondo, E., Navarro, I., \& Sánchez, A. (2014). Relationship between student profile, tool use, participation, and academic performance with the use of Augmented Reality technology for visualized architecture models. Computers in Human Behavior, 31, 434-445. 
Fowler Jr, F. J. (2013). Survey research methods (5th ed.). Sage Publications.

Fumagalli, L., Laurie, H., \& Lynn, P. (2013). Experiments with methods to reduce attrition in longitudinal surveys. Journal of the Royal Statistical Society: Series A (Statistics in Society), 176(2), 499-519.

Gedik, N., Hanci-Karademirci, A., Kursun, E., \& Cagiltay, K. (2012). Key instructional design issues in a cellular phone-based mobile learning project. Computers \& Education, 58(4), 1149-1159.

Gray, D. E., Ryan, M., \& Coulon, A. (2004). The training of teachers and trainers: Innovative practices, skills and competencies in the use of eLearning. European Journal of Open, Distance and e-learning, 7(2): 1.

Harsanto, B. (2014). Innovation to enhance blended learning experience: Applying Google sites in higher education. Information Management and Business Review, 6(1), $17-24$.

Hassad, R. A. (2013). Faculty attitude towards technology-assisted instruction for introductory statistics in the context of educational reform. Technology Innovations in Statistics Education, 7(2): 10.

Hibbert, P., Sillince, J., Diefenbach, T., \& Cunliffe, A. L. (2014). Relationally reflexive practice: A generative approach to theory development in qualitative research. Organizational Research Methods, 17(3), 278-298.

Huang, E. Y., Lin, S. W., \& Huang, T. K. (2012). What type of learning style leads to online participation in the mixed-mode e-learning environment? A study of software usage instruction. Computers \& Education, 58(1), 338-349.

Hussein, A. (2009). The use of triangulation in social sciences research: Can qualitative and quantitative methods be combined? Journal of Comparative Social Work, 4(1): 8.

Hustad, E., \& Arntzen, A. A. B. (2013). Facilitating teaching and learning capabilities in social learning management systems: Challenges, issues, and implications for design. Journal of Integrated Design and Process Science, 17(1), 17-35.

Imamoglu, S. Z. (2007). An empirical analysis concerning the user acceptance of elearning. Journal of American Academy of Business, 11(1), 132-137.

Isabirye, A. K., \& Dlodlo, N. (2014). Perceived inhibitors of innovative e-learning teaching practice at a South African University of Technology. Mediterranean Journal of Social Sciences, 5(4), 390-398.

Johnson, R. B., \& Onwuegbuzie, A. J. (2004). Mixed methods research: A research paradigm whose time has come. Educational researcher, 33(7), 14-26.

Joint Information Systems Committee (JISC). (2004). Effective practice with e-learning: A good practice guide in designing for learning. Bristol, UK: Higher Education Funding Council for Eaglish.

Kahu, E. R. (2013). Framing student engagement in higher education. Studies in Higher Education, 38(5), 758-773.

Keengwe, J., Onchwari, G., \& Agamba, J. (2014). Promoting effective e-learning practices through the constructivist pedagogy. Education and Information Technologies, 19(4), 887-898.

Khan, A. S., \& Nawaz, A. (2013). Role of contextual factors in using e-learning systems for higher education in developing countries. Journal of Educational Research and Studies, 1(4), 27-34.

Kristjansson, A. L., Sigfusson, J., Sigfusdottir, I. D., \& Allegrante, J. P. (2013). Data collection procedures for school-based surveys among adolescents: The youth in Europe study. Journal of School Health, 83(9), 662-667.

Lai, C., Wang, Q., Li, X., \& Hu, X. (2016). The influence of individual espoused cultural values on self-directed use of technology for language learning beyond the classroom. Computers in Human Behavior, 62, 676-688.

Lee, D. S., Lee, K. C., \& Seo, Y. W. (2015). An analysis of shared leadership, diversity, 
and team creativity in an e-learning environment. Computers in Human Behavior, 42 , 47-56.

Lee, Y. H., Hsieh, Y. C., \& Chen, Y. H. (2013). An investigation of employees' use of elearning systems: applying the technology acceptance model. Behaviour \& Information Technology, 32(2), 173-189.

Liu, J., Chan, S., Hung, A., \& Lee, R. (2002). Facilitators and inhibitors of e-learning. In L. C. Jain, R. J. Howlett, N. S. Ichalkaranje, \& G. Tonfoni (Eds.), Virtual Environments for Teaching and Learning (pp. 75-109). Singapore: World Scientific.

Lomas, D., Kumar, A., Patel, K., Ching, D., Lakshmanan, M., Kam, M., \& Forlizzi, J. L. (2013). The power of play: Design lessons for increasing the lifespan of outdated computers. In Proceedings of the SIGCHI Conference on Human Factors in Computing Systems (pp. 2735-2744). ACM.

Lonn, S., Teasley, S. D., \& Krumm, A. E. (2011). Who needs to do what where?: Using learning management systems on residential vs. commuter campuses. Computers \& Education, 56(3), 642-649.

Magsamen-Conrad, K., Upadhyaya, S., Joa, C. Y., \& Dowd, J. (2015). Bridging the divide: Using UTAUT to predict multigenerational tablet adoption practices. Computers in Human Behaviour, 50, 186-196.

Marshall, S. (2012). Determination of New Zealand tertiary institution e-learning capability: An application of an e-learning maturity model. Journal of Open Flexible and Distance Learning, 9(1), 58-63.

Martins, C., Oliveira, T., \& Popovič, A. (2014). Understanding the Internet banking adoption: A unified theory of acceptance and use of technology and perceived risk application. International Journal of Information Management, 34(1), 1-13.

Masrom, M., Zainon, O., \& Rahiman, R. (2008). Critical success in e-learning: An examination of technological and institutional support factors. International Journal of Cyber Society and Education, 1(2), 131-142.

McDonald, M., Gregory, S., Farley, H., Harlim, J., Sim, H. H., \& Newman, C. (2014). Coming of the third wave: A move toward best practice, user defined tools and mainstream integration for virtual worlds in education. In Proceedings of the 31st Australasian Society for Computers in Learning in Tertiary Education Conference (ASCILITE) (pp. 161-170).

McGee, P., \& Reis, A. (2012). Blended course design: A synthesis of best practices. Journal of Asynchronous Learning Networks, 16(4), 7-22.

Melnyk, S. A., Page, T. J., Wu, S. J., \& Burns, L. A. (2012). Would you mind completing this survey: Assessing the state of survey research in supply chain management. Journal of Purchasing and Supply Management, 18(1), 35-45.

Moghavvemi, S., Salleh, N. A. M., \& Abessi, M. (2013). Determinants of IT-related innovation acceptance and use behavior: Theoretical integration of unified theory of acceptance and use of technology and entrepreneurial potential model. Socialines Technologijos, 3(2), 243-260.

Mohammadyari, S., \& Singh, H. (2015). Understanding the effect of e-learning on individual performance: The role of digital literacy. Computers \& Education, 82, 1125.

Morgan, H. (2014). Focus on technology: Flip your classroom to increase academic achievement. Childhood Education, 90(3), 239-241.

Mulwa, C., Lawless, S., O’Keeffe, I., Sharp, M., \& Wade, V. (2012). A recommender framework for the evaluation of end user experience in adaptive technology enhanced learning. International Journal of Technology Enhanced Learning, 4(1/2), 67-84.

Nawaz, A. (2013). Using e-learning as a tool for education for all in developing states. International Journal of Science and Technology Education Research, 4(3), 38-46. 
Neuman, W. L., \& Robson, K. (2012). Qualitative interviewing. In Basics of social research qualitative and quantitative approaches (Custom edition for the University of Guelph) (pp. 187-203). Boston, MA: Pearson Education, Inc.

Noteborn, G., Dailey-Hebert, A., Carbonell, K. B., \& Gijselaers, W. (2014). Essential knowledge for academic performance: Educating in the virtual world to promote active learning. Teaching and Teacher Education, 37, 217-234.

Olasina, G. (2014). Exploring how users make sense of virtual worlds using the symbolic interaction theory. Journal of Gaming \& Virtual Worlds, 6(3), 297-311.

Olasina, G. (2016). Exploratory study of collaborative behaviour in gaming and interactions of students in Second Life. British Journal of Educational Technology, $47(3), 520-527$.

Onwuegbuzie, A. J., \& Leech, N. L. (2005). On becoming a pragmatic researcher: The importance of combining quantitative and qualitative research methodologies. International Journal of Social Research Methodology, 8(5), 375-387.

Osborne, J. W., \& Costello, A. B. (2009). Best practices in exploratory factor analysis: Four recommendations for getting the most from your analysis. Pan-Pacific Management Review, 12(2), 131-146.

Osipov, I. V., Nikulchev, E., Volinsky, A. A., \& Prasikova, A. Y. (2015). Study of gamification effectiveness in online e-learning systems. International Journal of Advanced Computer Science and Applications, 6(2), 71-77.

Paechter, M., Maier, B., \& Macher, D. (2010). Students' expectations of, and experiences in e-learning: Their relation to learning achievements and course satisfaction. Computers \& education, 54(1), 222-229.

Persico, D., Manca, S., \& Pozzi, F. (2014). Adapting the technology acceptance model to evaluate the innovative potential of e-learning systems. Computers in Human Behavior, 30, 614-622.

Puri, G. (2012). Critical success factors in e-learning-An empirical study. International Journal of Multidisciplinary Research, 2(1), 149-161.

Reilly, J. R., Vandenhouten, C., Gallagher-Lepak, S., \& Ralston-Berg, P. (2012). Faculty development for e-learning: A multi-campus community of practice (COP) approach. Journal of Asynchronous Learning Networks, 16(2), 99-110.

Reiska, P., Soika, K., \& Cañas, A. J. (2018). Using concept mapping to measure changes in interdisciplinary learning during high school. Knowledge Management \& ELearning (KM\&EL), 10(1), 1-24.

Riaz, A., \& Adnan, A. (2016). Acceptance of tablet apps for e-learning by senior users: A test of unified theory of acceptance and use of technology. Paper presented at the 8th PanCommonwealth Forum on Open Learning (PCF8).

Rossing, J. P., Miller, W., Cecil, A. K., \& Stamper, S. E. (2012). iLearning: The future of higher education? Student perceptions on learning with mobile tablets. Journal of the Scholarship of Teaching and Learning, 12(2), 1-26.

Samuel, M., Coombes, J. C., Miranda, J. J., Melvin, R., Young, E. J., \& Azarmina, P. (2004). Assessing computer skills in Tanzanian medical students: An elective experience. BMC Public Health, 4: 37.

Simeonova, B., Bogolyubov, P., Blagov, E., \& Kharabsheh, R. (2014). Cross-cultural validation of UTAUT: The case of University VLEs in Jordan, Russia and the UK. Electronic Journal of Knowledge Management, 12(1), 25-34.

Stepanyan, K., Littlejohn, A., \& Margaryan, A. (2013). Sustainable e-learning: Toward a coherent body of knowledge. Educational Technology \& Society, 16(2), 91-102.

Stokke, K., Olsen, N. R., Espehaug, B., \& Nortvedt, M. W. (2014). Evidence based practice beliefs and implementation among nurses: A cross-sectional study. BMC Nursing, 13: 8.

Tarhini, A., Hone, K. S., \& Liu, X. (2013). Factors affecting students' acceptance of e- 
learning environments in developing countries: A structural equation modeling approach. International Journal of Information and Education Technology, 3(1), 5459.

Tarhini, A., Teo, T., \& Tarhini, T. (2015). A cross-cultural validity of the e-learning acceptance measure (ElAM) in Lebanon and England: A confirmatory factor analysis. Education and Information Technologies, 21(5), 1296-1282.

Teach, R., \& Murff, E. (2014). Learning inhibitors in business simulations and games. Developments in Business Simulation and Experiential Learning, 36, 191-197.

Torrisi-Steele, G., \& Drew, S. (2013). The literature landscape of blended learning in higher education: The need for better understanding of academic blended practice. International Journal for Academic Development, 18(4), 371-383.

van Stam, G., \& van Greunen, D. (2014). Review of an African rural internet network and related academic interventions. The Journal of Community Informatics, 10(2), 116.

Van Winkle, C., Bueddefeld, J. N., MacKay, K. J., \& Halpenny, E. A. (2017). Factors affecting mobile device use at festival attractions. In Proceedings of the International Conference on Tourism Travel and Research Association: Advancing Tourism Research Globally. Retrieved from https://scholarworks.umass.edu/cgi/viewcontent.cgi?article=2107\&context=ttra

Venkatesh, V., Brown, S. A., \& Bala, H. (2013). Bridging the qualitative-quantitative divide: Guidelines for conducting mixed methods research in information systems. MIS quarterly, 37(1), 21-54.

Venkatesh, V., Morris, M. G., Davis, G. B., \& Davis, F. D. (2003). User acceptance of information technology: Toward a unified view. MIS Quarterly, 27(3), 425-478.

Wang, S., \& Tang, T. I. (2003). Assessing customer perceptions of web sites service quality in digital marketing environments. Journal of Organizational and End User Computing (JOEUC), 15(3), 14-31.

Weichhart, G., Stary, C., \& Appel, M. (2018). The digital Dalton Plan: Progressive education as integral part of web-based learning environments. Knowledge Management \& E-Learning (KM\&EL), 10(1), 25-52.

Workman, M. (2014). New media and the changing face of information technology use: The importance of task pursuit, social influence, and experience. Computers in Human Behavior, 31, 111-117. 